\title{
Feasibility Analysis of Household Industry Tape Timber in Bale Hakim Kampung, Lut Tawar District, Central Aceh Regency
}

\section{Eliyin $^{1}$, Ilma Fitri², Muhamad Yustisar ${ }^{3}$, Salmandi Putra ${ }^{4}$, Anna fitriana ${ }^{5}$, Siti Wahyu Ningsih ${ }^{6}$}

${ }^{1-6}$ Agribusiness Study Program, Faculty of Agriculture, Universitas Gajah Putih, Indonesia.

Corresponding Author: Eliyin

DOI: https://doi.org/10.52403/ijrr.20220117

\begin{abstract}
This study is a quantitative descriptive study to determine the costs, revenues, income and profits of a business and to determine the feasibility of cassava tape business in Bale Hakim village, Lut Tawar district, Central Aceh district. The methodology of this research is descriptive quantitative. Data analysis using R/C formula and Break Event Point. The results showed that the total cost of producing cassava tape for 3 months was RP. 5,007,000, with a total revenue of $13,730,000$, income $\mathrm{Rp}$. 9.520.000 and Profit Rp. 8,723,000. The result of the calculation of $\mathrm{R} / \mathrm{C}$ is greater than 1 , namely 2.742 , then the cassava tape industry is feasible to operate. The calculation results of BEP production $=5,007$ and Total Production $=$ 13,730, then BEP Production < Total Production, then the cassava tape business is in a profitable position. The results of the calculation of BEP receipts $=$ Rp. 5.007.000 and Revenue $=13.73$ million, then, BEP Revenue $<$ Acceptance, then the cassava tape business is in a profitable position. And the results of the calculation of BEP Price $=364.676$ and selling price $=$ Rp. 1000, then BEP Price $<$ Selling Price, then the cassava tape business is in a profitable position.
\end{abstract}

Keywords: Analysis, Business Feasibility, Home Industry, Cassava Tape

\section{INTRODUCTION}

The agricultural sector is an important part of the people's economy in Indonesia as an agricultural country.
Especially in the highlands of the Pressgon Gayo, Central Aceh Regency, which has fertile soil and adequate agricultural land. Most of the population in Aceh Tengah Regency make a living through agriculture. Cassava is one of the commodities in the food and horticulture sub-sector in Central Aceh Regency. The Gayo highland area as a tropical area allows this plant to thrive in this area. In Indonesia, this plant is the third source of food (carbohydrates) after rice and corn.

Based on data from the Central Aceh Regency Statistics Agency and the productivity of cassava in Central Aceh Regency for the last 3 years.

Table 1. Cassava Productivity in Central Aceh District 20182019

\begin{tabular}{|l|l|l|l|l|}
\hline No & Year & Planted Area & Harvested Area & production \\
\hline 1 & 2018 & $65,3 \mathrm{Ha}$ & $73,6 \mathrm{Ha}$ & $1.157,2 \mathrm{Ton}$ \\
\hline 2 & 2019 & $65,3 \mathrm{Ha}$ & $73,6 \mathrm{Ha}$ & $1.157,2$ Ton \\
\hline 3 & 2020 & 48 & 50,1 & 1.236 \\
\hline
\end{tabular}

Source: Central Aceh Statistics Agency data

Based on the data above, it can be seen that the land area for cassava planting in Aceh Tengah Regency is narrowing and productivity is decreasing. even though if we look at the fertility of the soil in Central Aceh, it has the potential to produce and can improve the community's economy from this cassava plant. there is a possibility that the relatively cheap price of cassava makes people less interested in producing this type of cassava food plant. 
Cassava tape is one of the processed cassava products that are in great demand in Indonesia in general. In one area in Central Aceh Regency, namely the Isak area, cassava tape is produced as souvenirs that have high demand and economic value. For other sub-districts in Central Aceh District, such as Lut Tawar District, this tape production is not carried out on a large scale. However, this type of food can be easily found in the market on a small scale.

The feasibility of cassava tape business needs to be studied to educate the community in Lut Tawar District in general to find out the potential for cassava tape production. There is a home-based cassava tape entrepreneur located in Lut Tawar District, Bale Hakim Village. This entrepreneur has been running his business by producing and selling cassava tape for 5 years. From his efforts, the researcher will study more deeply how the feasibility of this cassava tape business is.

According to Kasmir and Jakfar (2003:7) a business feasibility study means research conducted to determine whether the business being run will provide greater benefits than the costs to be incurred. In other words, feasibility can be interpreted that the business being run will provide financial and non-financial benefits in accordance with their desired goals.

According to Kasmir and Jakfar (2013:12) an entrepreneur is required to conduct a feasibility study on the business idea that will be carried out so that there is no investment delay in the future. The point is that if this business is carried out it will not be in vain or in other words it will not waste money, energy, or thoughts in vain and will not cause unnecessary problems in the future.

In a business that is run there is always a risk that must be accepted by the entrepreneur. Therefore, income analysis is very necessary in running a business to find out how much it costs and how much income the entrepreneur gets in running the business.

\section{LITERATURE REVIEW Feasibility Study}

According to Lilis (2016: 7) The definition of a business or business feasibility study is research involving various aspects, both from legal, socioeconomic and cultural aspects, market and marketing aspects, technical and technological aspects to management and financial aspects, where it is all used for the basis of research feasibility studies and the results are used to make a decision whether a project or business can be carried out or postponed or even discontinued.

Kasmir and Jakfar (2003:10) Feasibility means that in-depth research is carried out to determine whether the business to be carried out will provide greater benefits than the costs to be incurred. In other words, feasibility can be interpreted that the business that is run will provide financial and non-financial benefits in accordance with the goals they want.

According to Husnan (2014:9) a business feasibility study is research on whether or not an investment project can be implemented successfully. Success can be interpreted more broadly or more limitedly, which is mainly used by private parties who are more interested in the economic benefits of an investment.

According to Husein Umar (2005:8) a business feasibility study is a research on a business plan that not only analyzes whether it is feasible or not for a business to be built, but also when it is operated routinely in order to achieve maximum profit for an indefinite time.

According to Suliyanto (2010:13) very dynamic environmental conditions and the intensity of increasingly fierce competition make it not enough for an entrepreneur to rely on experience and intuition alone in starting his business. In addition, before a business idea is implemented, several parties other than business people also need a feasibility study with various interests.

According to Kasmir and Jakfar (2013:12) an entrepreneur is required to 
conduct a feasibility study of the business idea that will be carried out so that there will be no investment delays in the future. The point is that if this business is carried out it will not be in vain or in other words it will not waste money, energy, or thoughts in vain and will not cause unnecessary problems in the future.

\section{Home Industry Cassava Tape}

The definition of Industry according to Law No. 3 of 2014 is all forms of economic activity that processes raw materials and utilizes industrial resources so as to produce goods that have added value or higher benefits, including industrial services.

According to the Big Indonesian Dictionary (KBBI), industry is the activity of processing or processing goods using facilities and equipment.

Sritomo (2003:19) industry is an economic activity that manages raw materials, raw materials, semi-finished goods, and/or finished goods into goods with a higher value for their use, including industrial design and engineering activities. From a geographical point of view, industry as a system is a combination of physical sub-systems and human sub-systems.

Meanwhile, the Central Bureau of Statistics states that industry is a business unit that carries out economic activities, aims to produce goods or services, and is located in a building or a certain location and has administrative records regarding production and its cost structure.

$$
\begin{aligned}
& \text { NR }=\text { TR }- \text { explicit } \mathbf{T C} \\
& \text { TR }=\mathbf{P} \mathbf{x} \mathbf{Q} \\
& \text { Description: } \\
& \text { NR } \quad \text { Income } \\
& \text { TR } \quad \text { : Total Revenue (Receipts) } \\
& \text { TC } \quad \text { : Total cost (Total cost) } \\
& \text { P } \quad \text { : Price (Price per unit of output) } \\
& \text { Q : Quantity (Output) }
\end{aligned}
$$

According to Nur Rianto (2010:167) profit or loss is the difference between sales and production costs. Profits are obtained if the sales proceeds exceed the production costs, and losses will be experienced if the sales results are less than the production costs. Maximum profit is achieved when the difference between sales and production costs reaches the greatest level. Suparmoko (2011:49-51) Profit or loss is the difference between sales and production costs. Profits are obtained if the sales proceeds exceed the production costs, and losses will be experienced if the sales results are less than the production costs. Maximum profit is achieved when the difference between sales and production costs reaches the greatest level.

According to Sadono Sukirno (2013: 384) profit according to the bookkeeping perspective, if further reduced by hidden costs, will result in economic profit or pure profit (Pure Profit). In economic theory, when stated "profit" is meant economic profit.

Mathematically the maximum profit can be calculated using the following formula: $=\mathrm{TR}-\mathrm{TC}$

Description:

(Profit) $=$ amount of profit

TR $($ Total Revenue $)=$ total revenue TC $($ Total Cost $)=$ total cost

According to Wilson Bangun (2007.101) the greater the difference between the total revenue and the total cost, the greater the profit earned on the sale of these goods. On the other hand, the smaller the profit, the smaller the difference between total revenue and total cost. Profit is zero (zero profit) when total revenue equals total cost, and a loss when total revenue is less than total cost.

\section{Break Event Point (BEP)}

The definition of a Break Event Point according to Kasmir (2011:332) is a condition where the company operates in a condition that does not earn income (profit) and does not suffer losses. This means that in this condition the amount of income received is equal to the amount of costs incurred. According to Bambang Riyanto 
(2011:359) states that a technique to determine the relationship between fixed costs, variable costs, profits and activity volume.

Break Event Point (BEP) is the break-even point in a business. The BEP value can be seen at the level of production and at what price a business does not make a profit or loss. there are three types of BEP calculations, namely production BEP, revenue $\mathrm{BEP}$, and price $\mathrm{BEP}$ which are formulated as follows (Prawirosentono, 2009:42):

\section{1) Production BEP}

$Q=\frac{T C}{P}$

Where:

Q: Product Selling Price

TC: Total Cost

Q: The resulting product

\section{2) BEP Admission}

$$
P=\frac{T F C}{P}
$$

Where:

TFC: Fixed costs

Q: Selling price per unit

Meanwhile, for BEP acceptance, the criteria are as follows:

a. If BEP Acceptance < Acceptance, then the business is in a profitable position.

b. If BEP Revenue = Revenue, then the business is at the break-even point or no profit/no loss.

c. If BEP Acceptance > Acceptance, then the business is at a disadvantage.

\section{3) BEP Price}

$$
P=\frac{T C}{Q}
$$

Where:

Q: Product Selling Price

TC: Total Cost

Q: The resulting product

Production BEP criteria are as

follows:

a. If BEP Production < Total Production, then the business is in a profitable position. b. If BEP Production = Total Production, then the business is at the break-even point or no profit/no loss.

c. If BEP Production > Total Production, the business is in an unprofitable position.

d. Meanwhile, for BEP the price criteria are as follows:

e. If BEP Price < Selling Price, then the business is in a profitable position.

f. If BEP Price = Selling Price, then the business is at the break-even point or no profit/no loss.

g. If BEP Price $>$ Selling Price, then the business is in an unprofitable position.

\section{MATERIALS \& METHODS}

The scope of this research is limited to business feasibility analysis by considering financial aspects, namely income, revenue and profit. In this study, the determination of the sample was carried out using a purposive method, namely intentionally by considering the presence of a sample of the cassava tape home industry in Bale Hakim village, Lut Tawar District, Central Aceh Regency. To find out the amount of costs, revenues, revenues and profits of a business, data analysis techniques are carried out using the following equations:

To find out the total cost use the formula:

TC $=$ TEC + TIC

Description:

TC: Total Cost (total cost)

TEC: Total Explicit Cost

TIC: Total Implicit Cost (total implicit cost) Revenue Cost Ratio (R/C)

To find out the value of $\mathrm{R} / \mathrm{C}$, the formula is used:

$\mathrm{R} / \mathrm{C}=\frac{T R}{T C}$

Description:

$\mathrm{R} / \mathrm{C}$ : Revenue Cost Ratio

TR: Total Revenue (Total revenue)

TC: Total Cost (Total cost)

Provision:

- If the $\mathrm{R} / \mathrm{C}$ is greater than 1 , then the cassava tape industry is feasible to operate. 
Eliyin et.al. Feasibility analysis of household industry tape timber in Bale Hakim Kampung, Lut Tawar District, Central Aceh Regency.

- If the $\mathrm{R} / \mathrm{C}$ value is less than or equal to 1 , then the cassava tape industry is not feasible to operate.

\section{Break Event Points (BEP)}

\section{Production BEP}

$$
\text { Production BEP }=\frac{\text { Total } \cos t}{\text { sellingprice }}
$$

2. BEP Revenue $=$ Total cost or total cost (TC)

Meanwhile, for BEP acceptance, the criteria are as follows:

\section{RESULT}

The total costs referred to in this study are the explicit and implicit costs incurred. Explicit costs are fixed costs incurred every time the production includes Cassava, because Cassava is purchased every time it is produced. Other staples such as sticks, sugar, yeast, banana leaves, and sweet juice are included in the depreciation expense. Implicit costs are costs incurred for equipment that is not always purchased every time it is produced, such as spoons, basins, knives and other supporting equipment.

Based on the data that has been collected, it was found that the total explicit cost $=4,210,000$ and the total implicit cost $=$ 797,000 . Then the total cost can be determined as follows: formula:

To find out the total cost use the

$\mathrm{TC}=\mathrm{TEC}+\mathrm{TIC}$

Description:

TC: Total Cost (total cost)

TEC: Total Explicit Cost

TIC: Total Implicit Cost (total implicit cost)

So the total production cost of cassava tape entrepreneurs for 3 months or 55 times of production is as follows

$\mathrm{TC}=4,210,000+797,000$

$\mathrm{TC}=5,007,000$

So the total cost of producing cassava tape for 3 months is RP. 5,007,000.

\section{Reception}

Revenue is the total revenue earned by the entrepreneur. the selling price of cassava tape per pack is Rp.1,000. and the total production of cassava tape for 3 months is 13,730 packs. To calculate the revenue obtained, use the formula:

$\mathrm{TR}=\mathrm{P} \times \mathrm{Q}$

Description:

TR: Total Revenue (Business revenue)

P: Price (Product selling price)

Q: Quantity (Number of products produced)

So the acceptance of cassava tape entrepreneurs for 3 months or 55 times of production is as follows:

$\mathrm{TR}=1000 \times 13,730$

$\mathrm{TR}=13,730,000$

So, the total revenue from cassava tape entrepreneurs for 3 months is 13,730,000.

\section{Income} formula:

To find out income can use the $\mathrm{NR}=\mathrm{TR}-\mathrm{TEC}$

Description:

NR: Net Revenue (Revenue)

TR: Total Revenue (Receipts)

TEC: Total Explicit (Total Explicit cost)

It was found that the total revenue was Rp. 13,730,000 and the total explicit cost is Rp. 4,210,000:

$\mathrm{NR}=13,730,000-4,210,000$

$\mathrm{NR}=9,520,000$

So the income of cassava tape entrepreneurs for 3 months or 55 times of production is Rp. 9,520,000.

\section{Profit}

To calculate profit using the formula:

$=\mathrm{TR}-\mathrm{TC}$

Description:

: Profit

TR: Total Revenue (Receipts)

TC: Total Cost (Total Cost (Explicit + Implicit)

Based on research data obtained total revenue is Rp. 13,730,000 and the total cost (explicit + implicit) is RP. 5,007,000.

$=13,730,000-5,007,000$

$=8,723,000$ 
Eliyin et.al. Feasibility analysis of household industry tape timber in Bale Hakim Kampung, Lut Tawar District, Central Aceh Regency.

So the profit of cassava tape entrepreneurs for 3 months or 55 times of production is Rp. 8,723,000.

Feasibility

Revenue Cost Ratio (R/C)

Depreciation: Rp. 1,185,999.997

Total Cost: Rp. 5,007,000

Revenue: Rp. 13,730,000

Income: Rp. 9,520,000

Profit: Rp. 8,723,000

Production Results: 13,730 Packs

To find out the value of $\mathrm{R} / \mathrm{C}$, the formula is used:

$\mathrm{R} / \mathrm{C}=\frac{T R}{T C}$

Description:

R/C : Revenue Cost Ratio

TR : Total Revenue (Total revenue)

TC : Total Cost (Total cost)

Based on research data obtained total revenue is Rp. $13,730,000$ and the total cost is RP. 5,007,000. So:

$R / C=\frac{13.730 .000}{5.007 .000}$

$R / C=2,742$

Provision:

- If the $\mathrm{R} / \mathrm{C}$ is greater than 1 , then the cassava tape industry is feasible to operate.

- If the $\mathrm{R} / \mathrm{C}$ value is less than or equal to 1 , then the cassava tape industry is not feasible to operate.

Based on the results of the calculation of $\mathrm{R} / \mathrm{C}$ greater than 1 , namely 2.742, then the cassava tape industry is feasible to operate.

\section{Break Event Points (BEP)}

Production BEP

Production BEP $=\frac{\text { Total } \cos t}{\text { sellingprice }}$

Based on the research data, the total cost is RP. 5,007,000 with a selling price of 1,000 . So:

Production BEP $=\frac{5.007 .000}{1000}$

Production BEP $=5.007$
Production BEP criteria are as follows:

a. If BEP Production < Total Production, then the business is in a profitable position.

b. If BEP Production = Total Production, then the business is at the break-even point or no profit/no loss.

c. If BEP Production > Total Production, the business is in an unprofitable position.

Based on the calculation results of BEP production $=5,007$ and Total Production $=13,730$, then, BEP Production $<$ Total Production, then the cassava tape business is in a profitable position.

\section{BEP Admission}

BEP Revenue $=$ Total Cost or Total Cost (TC)

$=$ Rp. 5,007,000

For BEP acceptance the criteria are as follows:

a. If BEP Acceptance < Acceptance, then the business is in a profitable position.

b. If BEP Revenue = Revenue, then the business is at the break-even point or no profit/no loss.

c. If BEP Acceptance > Acceptance, then the business is at a disadvantage.

Based on the results of the calculation of BEP revenue $=$ Rp. 5.007.000 and Revenue $=13.73$ million, then, BEP Revenue < Acceptance, then the cassava tape business is in a profitable position.

BEP Price $P=\frac{T C}{Q}$

Where:

Q : Product Selling Price

TC : Total Cost

Q: The resulting product

Based on the research data, the total cost is RP. 5,007,000 and the resulting product is 13,730 packs. So: 
Eliyin et.al. Feasibility analysis of household industry tape timber in Bale Hakim Kampung, Lut Tawar District, Central Aceh Regency.

$P=\frac{5.007 .000}{13.730}$
$P=364,676$

Meanwhile, for BEP the price criteria are as follows:

- If BEP Price < Selling Price, then the business is in a profitable position.

- If BEP Price = Selling Price, then the business is at the break-even point or no profit/no loss.

- If BEP Price > Selling Price, then the business is in an unprofitable position.

Based on the calculation results of BEP Price $=364.676$ and selling price $=\mathrm{Rp}$. 1000 , then BEP Price < Selling Price, then the cassava tape business is in a profitable position.

\section{CONCLUSION}

The total cost of producing cassava tape for 3 months is RP. 5,007,000, with a total revenue of $13,730,000$, an income of Rp. 9.520.000 and Profit Rp. 8,723,000. The result of the calculation of $\mathrm{R} / \mathrm{C}$ is greater than 1 , namely 2.742 , then the cassava tape industry is feasible to operate. The calculation results of BEP production = 5,007 and Total Production $=13,730$, then BEP Production < Total Production, then the cassava tape business is in a profitable position. The results of the calculation of $\mathrm{BEP}$ receipts $=$ Rp. 5.007.000 and Revenue $=13.73$ million, then, BEP Revenue < Acceptance, then the cassava tape business is in a profitable position. And the results of the calculation of BEP Price $=364.676$ and selling price $=$ Rp. 1000 , then BEP Price $<$ Selling Price, then the cassava tape business is in a profitable position.

\section{Acknowledgement: None}

Conflict of Interest: None

Source of Funding: None

\section{REFERENCES}

1. Abubakar,. Wibowo. (2004). Akuntansi. Untuk. Bisnis:Usaha Kecil dan Menengah. PT. Gramedia, Jakarta

2. Andi Fitriani (2018), Analisis Kelayakan Finansial Usaha Pengolahan Gula Aren Di Kabupaten Sinjai. Fakultas ekonomi dan bisnis islam uin alauddin makassar

3. Bambang Riyanto. (2011), Dasar - Dasar Pembelanjaan Perusahaan, Edisi. Keempat, Cetakan Ketujuh, YBPFE UGM, Yogyakarta

4. Budi Saputra Sinaga (2018), Analisis Kelayakan Usaha Industri Tahu Di Desa Banyuraden Kecamatan Gamping Kabupaten Sleman Yogyakarta. Fakultas pertanian universitas muhammadiyah Yogyakarta

5. Emawati. (2007). Analisis Kelayakan Finansial Industri Tahu (Studi Kasus: Usaha Dagang Tahu Bintaro, Kabupaten Tangerang Propinsi Banten). Fakultas Sains Dan Teknologi UIN Syarif Hidayatullah Jakarta

6. Freddy Rangkuti. (2009). Strategi Promosi yang Kreatif dan Analisis Kasus Integrated Marketing Communication. PT. Gramedia Pustaka Utama, Jakarta

7. Husein Umar, (2005) Studi Kelayakan Bisnis, edisi 3 revisi: PT.Gramedika Pustaka Utama, Jakarta

8. Husein Umar. (2009). Rencana Kerja Perusahaan Yang Baik. Rajawali, Jakarta

9. Husnan, Suad \& Suwarsono Muhammad. (2014). Studi Kelayakan Proyek Bisnis Edisi. Kelima. UPP STIM YKPN, Yogyakarta

10. Kamus Besar Bahasa Indonesia (KBBI)

11. Kasmir dan Jakfar (2003) Studi Kelayakan Bisnis, Edisi Pertama,Prenadamedia: Jakarta

12. Kasmir dan Jakfar. (2012) Studi Kelayakan Bisnis. Kencana Prenada Media Group, Jakarta

13. Kasmir,(2011), Analisis Laporan Keuangan, Raja Grafindo Persada: Jakarta

14. Kasmir. Jakfar. (2013) Studi Kelayakan Bisnis. Edisi revisi. Kencana, Jakarta

15. Kotler dan Keller. (2009). Manajemen Pemasaran. Jilid I. Edisi ke 13, Erlangga, Jakarta

16. Kuswadi. (2005). Meningkatkan Laba Melalui Pendekatan Akuntansi Keuangan dan Akuntansi Biaya. Jakarta: PT Elex Media Komputindo. 
Eliyin et.al. Feasibility analysis of household industry tape timber in Bale Hakim Kampung, Lut Tawar District, Central Aceh Regency.

17. Lilis Sulastri (2016), Studi Kelayakan Bisnis Untuk Wirausaha, LaGood's Publishing

18. M. Nur Rianto Al Arif, Dr. Euis Amalia (2010) Teori Mikroekonomi: Suatu Perbandingan Ekonomi Islam dan Ekonomi Konvensional . Kencana, Jakarta

19. Mimit Primyastanto, (2015), Ekonomi Perikanan, Intelegensi Media, Malang

20. Rahardi, F. \& Hartono. (2003) Agribisnis Peternakan., Ed rev. Penebar Swadaya, Jakarta

21. Rosdiana (2011), “Analisa Pendapaan dan Studi Kelayakan Industri Rumah Tangga Tape Ubi Kayu Studi Kasus pada Kampong Gelampang Gading Kecamatan Linge Kabupaten Aceh Tengah). Program Studi Agribisnis Fakultas Pertanian Universitas Gajah Putih Takengon

22. Sadono Sukirno, (2013) Mikroekonomi Teori Pengantar, Edisi Ketiga, PT Raja Grafindo Persada, Jakarta

23. Suherman, Rosyidi (2003) Pengantar Teori Ekonomi: Pendekatan Kepada Teori Ekonomi Mikro dan Makro Raja Grafindo Persada, Jakarta.
24. Suliyanto, (2010) Studi kelayakan bisnis pendekatan praktis, Edisi satu, Andi offset, Yogyakarta

25. Suparmoko,( 2011) Teori Ekonomi Mikro, Edisi 1 BPFE-Yogyakarta, Yogyakarta

26. Sritomo Wignjosoebroto, 2003, Pengantar Teknik \& Manajemen Industri Edisi Pertama, Penerbit Guna widya, Jakarta

27. Tia Aprilia Zakita (2018), “Analisis Kelayakan Usaha pada Industri Tempe di Desa Purwodadi Dalam Kecamatan Tanjung Sari Kabupaten Lampung Selatan”. Fakultas Ekonomi Dan Bisnis Universitas Lampung Bandar Lampung

28. Undang-Undang Nomor 9 Tahun 1995, kriteria usaha kecil

29. Wilson Bangun, (2007) Teori Ekonomi Mikro, PT Refika Aditama, Bandung

How to cite this article: Eliyin, Ilma Fitri, Muhamad Yustisar et.al. Feasibility analysis of household industry tape timber in Bale Hakim Kampung, Lut Tawar District, Central Aceh Regency. International Journal of Research and Review. 2022; 9(1): 121-128. DOI: https://doi. org/10.52403/ijrr.20220117 